\title{
Implikasi Pengujian Undang-undang oleh Mahkamah Konstitusi dalam Mewujudkan Maqashid Syari'ah
}

\author{
Septi Nur Wijayanti, Tanto Lailam
}

\section{DATA NASKAH:}

Masuk: 22 November 2017

Diterima: 01 Oktober 2018

Terbit: 31 Desember 2018

KORESPONDEN PENULIS:

Fakultas Hukum Universitas Muhammadiyah Yogyakarta

Jalan Brawijaya, Tamantirto, Kasihan,

Bantul, Yogyakarta, 55183

Email:

septinurwijayanti73@gmail.com

tanto.tatanegara@gmail.com

\begin{abstract}
This research is about the implications of constitutional review by Constitutional Court in realizing maqashid sharia backgrounded by the ambiguity of whether or not to use the maqashid syariah as a benchmark in constitutional review. The research is to observe the use of maqashid syariah as a benchmark and the implications of the legal system in Indonesia. The method used is normative legal research focusing on several decisions of Constitutional Court. The results of the study show that the Constitutional Court accommodates maqashid sharia. Based on the analysis of Constitutional Court Verdict Number 2-3/ PUU-V/2007, Verdict Number 12/PUU-V/2007, Verdict Number 68/PUU-XII/2014, Verdict Number 85/PUU-XI/2013 show that in constitutional review, the Constitutional Court uses the maqashid syariah as a benchmarks (in the framework of Pancasila) in line with the idealization of Baldatun Thayyibatun wa Rabbun Ghafur meant to maqashid syariah focusing on maintaining the benefit of religion / din, maintaining the benefit of the soul / nafs, maintaining the benefit of reason / aql, maintaining the benefit of descendants / nasl, and maintaining the benefit of wealth / mal) has been accommodated and applied in constitutional review. The implication is that maqashid sharia becomes one of benchmarks in constitutional review and the Constitutional Court can intepret the contextualization of maqashid sharia in various cases.
\end{abstract}

Keywords: Constitutional Review, Constitutional Court, Maqashid Syariah

\section{ABSTRAK}

Penelitian ini mengenai implikasi Pengujian Undang-undang oleh Mahkamah Konstitusi dalam mewujudkan maqashid syariah, yang dilatarbelakangi oleh ketidakjelasan boleh/ tidaknya menggunakan tolok ukur maqashid syariah dalam pengujian undang-undang. Tujuan penelitian untuk melihat penggunaan tolok ukur maqashid syariah dan implikasi yang ditimbulkan terhadap sistem hukum di Indonesia. Metode yang digunakan dalam penelitian ini adalah Penelitian hukum normatif yang memfokuskan pada beberapa putusan MK. Hasil penelitian menunjukkan bahwa MK mengakomodasi maqashid syariah. Berdasarkan analisis terhadap Putusan MK No.2-3/PUU-V/2007, Putusan MK No.12/PUU-V/2007, Putusan MK 
No.68/PUU-XII/2014, Putusan MK No.85/PUU$\mathrm{XI} / 2013$ menunjukkan bahwa dalam pengujian undang-undang, MK menggunakan tolok ukur maqashid syariah dalam kerangka bernegara Pancasila yang sejalan dengan idealisasi Baldatun Thayyibatun wa Rabbun Ghafur, artinya secara substantif maqashid syariah yang menitikberatkan pada memelihara kemaslahatan agama/ din, memelihara kemaslahatan jiwa/ nafs, memelihara kemaslahatan akal/ aql, memelihara kemaslahatan keturunan/ nasl, dan memelihara kemaslahatan harta/ mal) telah diakomodir dan diterapkan dalam pengujian undangundang. Implikasinya adalah maqashid syariah menjadi salah satu tolok ukur dalam pengujian undangundang dan MK dalam melakukan pengujian undang-undang dapat menafsirkan kontekstualisasi maqashid syariah dalam berbagai kasus.

Kata Kunci: Pengujian Undang-undang, Mahkamah Konstitusi, Maqashid Syariah

\section{PENDAhuluan}

Siyasah Syari'ah merupakan kebijaksanaan dalam mengatur urusan publik sesuai dengan norma syari'ah, baik ketika memberlakukan hukum/ peraturan ataupun memutuskan perkara di pengadilan. Ibn Taimiyah menyatakan bahwa konsep siyasah syari'ah bisa digunakan untuk menjustifikasi pemberlakuan dan penegakan hukum/ peraturan/ putusan yang dilakukan oleh negara sepanjang materi hukum/ peraturan/ putusan tersebut tidak keluar dari batas yang telah ditetapkan oleh ulama, dan hukum/ peraturan/ putusan tadi memajukan kesejahteraan umum. Pemikiran Ibn Taimiyah terkait siyasah syari'ah adalah logis untuk menjawab persoalan dikotomi otoritas hukum antara Islam dan negara karena dengan siyasah syari'ah dampak berlebihan dari kebijakan penguasa bisa dibatasi dan legitimasi norma syari'ah bisa diperluas sampai pada tataran kehidupan bernegara (Alfitri, 2014: 298).

Pada sisi lain, Abu Ishaq al Shatibi menilai bahwa siyasah syari'ah meningkatkan efektivitas pencapaian tujuan yang ingin dicapai dalam kehidupan bermasyarakat, berbangsa dan bernegara (maqashid syari'ah: memelihara kemaslahatan agama/ din, memelihara kemaslahatan jiwa/ nafs, memelihara kemaslahatan akal/ aql, memelihara kemaslahatan keturunan/ nasl, dan memelihara kemaslahatan harta/ mal) (Ali Imron, 2015: 51). Pandangan Ibn Taimiyah tersebut dapat dibenarkan, hal ini terlihat perkembangan politik ketatanegaraan di berbagai belahan dunia. Bahkan, ketentuan tentang wajibnya hukum negara konsisten dengan norma syari'ah semakin banyak diadopsi oleh negara Islam atau berpenduduk mayoritas muslim dalam beberapa dekade terakhir. Diantara negara-negara ini adalah: Afghanistan (lihat Pasal 3 Afghan Constitution); Mesir (lihat Pasal 2 Egyptian Constitution); Iran (lihat Pasal 2 4 Iranian Constitution); Pakistan (lihat Pasal 227 Pakistani Constitution); Qatar (lihat Pasal 1 of Qatari Constitution); Yaman (lihat Pasal 3 of Yemeni Constitution); and Arab Saudi (lihat Basic Law yang menyatakan bahwa syariah adalah hukum yang mengikat dan semua peraturan perundang-undangan yang bertentangan dengan syariah tidak dapat diterapkan) (Alfitri, 2014: 298).

Hal ini senada dengan kondisi Indonesia, sekalipun Indonesia bukan merupakan negara Islam, tetapi Indonesia merupakan negara muslim (Indonesia sebagai negara yang berpenduduk terbanyak beragama Islam). Sila ke-1 Pancasila yang berbunyi "Ketuhanan Yang Maha Esa" tersebut dapat dipahami sebagai nilai tauhid (ajaran Islam) dalam kehidupan berbangsa dan bernegara. Intinya bahwa di dalam nilai ketauhidan tersebut terdapat anjuran untuk untuk meyakini bahwa Allah SWT ikut berperan dalam kehidupan berbangsa dan bernegara melalui nilai-nilai ajaran ketauhidan dalam Islam. Namun, ajaran Islam juga memberikan toleransi, kebebasan, dan kesempatan yang seluas-luasnya bagi pemeluk agama lain untuk melaksanakan ajaran mereka masing-masing. Selain itu, terdapat persamaan antara nomokrasi Islam dengan negara hukum Pancasila, prinsip-prinsip pokok yang terdapat 
dalam demokrasi Islam (musyawarah, keadilan, persamaan, dan kebebasan) secara yuridis konstitusional baik eksplisit maupun implisit dapat dibaca dalam UUD 1945.

Merujuk hal di atas bahwa Indonesia adalah negara yang Islami, dan tentunya Pancasila dan UUD 1945 juga Islami (sesuai dengan al Qur'an dan Sunnah). Di Indonesia, penerapan dan formalisasi Siyasah Syari'ah (maqashid syari'ah) dapat dilakukan melalui berbagai kebijakan negara, baik oleh eksekutif, legislatif maupun yudikatif, baik melalui bentuk produk hukum (peraturan perundangundangan) maupun putusan peradilan. Dengan terbentuknya MK sebagai lembaga penafsir sah terhadap UUD 1945 atau konstitusi (the legitimate interpreter of the constitution) (I Dewa Gede Palguna, 2008: 17) yang kewenangannya melakukan pengujian undang-undang tentu akan membuat predikat $\mathrm{MK}$ dalam menambah kuatnya konstitusionalisme Islam di Indonesia, umat Islam di Indonesia dapat menggugat keabsahan dan tafsiran hukum Islam versi pemerintah, bahkan bisa menggugat undang-undang yang bertentangan dengan syariah Islam (konstitusionalisme Islam). MK menjelma sebagai tempat untuk menetapkan pada tataran apa hukum Islam harusnya diterapkan, difasilitasi, atau dipaksakan oleh institusi Negara (Alfitri, 2014: 298).

Dalam pandangan Jimly Asshiddiqie (2006: 7) salah satu tolok ukur dalam menguji adalah nilainilai konstitusi yang hidup (the living constitution) yang meliputi di dalamnya nilai-nilai konstitusionalisme Islam (maqashid syariah.

\section{RUMUSAN MASALAH}

Berdasarkan latar belakang di atas, maka perlu dirumuskan permasalahan utama dalam rumusan masalah di bawah ini:

(1) apakah dalam pengujian undang-undang oleh MK digunakan tolok ukur maqashid syariah?; dan

(2) apa implikasi pengujian undang-undang oleh MK dalam mewujudkan maqashid syariah?

\section{METODE PENELITIAN}

\section{A. Tipe dan Pendekatan Penelitian}

Penelitian hukum merupakan penelitian yang diterapkan atau diberlakukan khusus pada ilmu hukum, yang membantu pengembangan ilmu hukum dalam mengungkap suatu kebenaran hukum, penelitian ini mengenai implikasi pengujian konstitusional dalam mewujudkan maqashid syari'ah. Penelitian yang dipilih adalah penelitian doktrinal, penelitian hukum doktrinal adalah penelitian hukum yang meletakkan hukum sebagai sebuah bangunan sistem norma, sistem norma yang dimaksud adalah mengenai asas-asas, norma, kaidah dari peraturan perundang-undangan, putusan pengadilan, perjanjian serta doktrin (ajaran). Penelitian hukum doktrinal dalam hal ini digunakan beberapa pendekatan, pendekatan perundang-undangan, pendekatan analitis (analytical approach), dan pendekatan kasus (case approach). Pendekatan kasus mengkaji ratio decidendi (pertimbangan hukum atau reasoning), pertimbangan hakim tersebut dapat dijadikan referensi bagi ketajaman analisis yang akan dilakukan (Mukti Fajar dan Yulianto Achmad, 2005: 187-191).

\section{B. Sumber Data}

Sumber data dalam penelitian ini adalah data sekunder. Data sekunder adalah data yang diperoleh berdasarkan studi pustaka, penelitian terhadap data sekunder yang berasal dari peraturan perundangundangan, catatan-catatan resmi atau risalah resmi, putusan hakim, buku, dan lainnya. Data sekunder tersebut dibagi menjadi tiga kelompok bahan hukum, yaitu: bahan hukum primer, bahan hukum sekunder, dan bahan hukum tersier, meliputi: Bahan hukum primer merupakan bahan hukum yang mengikat, terdiri dari peraturan perundang-undangan, catatan resmi atau risalah dalam pembuatan peraturan perundang-undangan, dan putusan hakim. Adapun peraturan perundang-undangan, sebagai bahan hukum primer meliputi: Undang-Undang Dasar 1945; Undang-undang No. 24 Tahun 2003 tentang Mahkamah Konstitusi; Undang-Undang No.8 Tahun 
2011 tentang Perubahan Atas Undang-undang No. 24 Tahun 2003 tentang Mahkamah Konstitusi; dan Peraturan Mahkamah Konsitusi Nomor 06/PMK/2005 tentang Pedoman Beracara dalam Perkara Pengujian Undang-Undang, dan peraturan terkait lainnya. Putusan MK yang telah memiliki kekuatan hukum tetap sebagai bahan hukum primer, berdasarkan penggunaan non-random sampling dengan pendekatan purposive sampling (sampel bertujuan), sampel yang diambil memiliki ciri spesifik yang dimilikinya pemilihan sampel harus disertai argumentasi berupa karakteristik sampel yang dipilih, Menurut Maria SW Sumardjono (1997:29), peneliti menggunakan pertimbangan sendiri dengan berbekal pengetahuan yang cukup tentang populasi untuk memilih anggota-anggotanya sampel, data yang diperoleh dari purposive sampling paling banyak memberikan arah pada kesimpulan. Berdasarkan pendekatan tersebut, maka peneliti memilih 4 putusan MK yang memiliki ciri atau karakteristik khusus dari jumlah perkara yang diputus oleh MK kurun waktu tahun 2003 - 2016. Putusan MK yang dipilih dengan pendekatan sampel bertujuan memiliki ciri atau karakteristik khusus yang mengarah pada data yang dibutuhkan dalam fokus studi penelitian ini (putusan yang memiliki relevansi dengan syariah Islam).

\section{Pengumpulan Data}

Teknik pengumpulan data dilakukan dengan dua cara penelitian kepustakaan (library research) atau disebut dengan studi dokumen, studi pustaka terhadap bahan hukum primer, bahan hukum sekunder, dan bahan hukum tersier. Penelusuran bahan-bahan hukum tersebut dapat dilakukan dengan membaca, melihat, mendengar bahan hukum tersebut.

\section{Analisis Data}

Analisis data dalam penelitian ini menggunakan deskriptif kualitatif. Analisis deskriptif dimaksudkan adalah peneliti dalam menganalisis berkeinginan untuk memberikan gambaran atau pemaparan atas objek penelitian sebagaimana hasil penelitian yang dilakukan. Pendekatan analisa secara deskriptif kualitatif dilakukan dengan memperlakukan obyek berdasarkan kategori tertentu, kategori tersebut bertujuan untuk menyeleksi data yang berkaitan dengan penelitian, kemudian diklasifikasikan secara yuridis dan sistematis. Tahapan analisis data dalam penelitian hukum, yaitu: (1) bahan hukum atau fakta disistematisasi atau ditata dan disesuaikan dengan objek yang diteliti; (2) Bahan hukum atau fakta yang telah disistematisasi, kemudian diuraikan dan dijelaskan sesuai objek yang diteliti berdasarkan teori; (3) Bahan hukum yang telah diuraikan kemudian dievaluasi, dinilai dengan menggunakan ukuran hukum yang berlaku, sehingga ditemukan ada yang sesuai dan ada yang tidak sesuai dengan hukum yang berlaku. Pada tahap ini dilakukan beberapa aktivitas dilakukan seperti halnya mengumpulkan berbagai putusan dan literatur lainnya. (4) Langkah tersebut dilakukan untuk memahami fokus penelitian secara mendalam penyusunan secara sistematis dimaksudkan untuk memberikan gambaran secara komprehensif.

\section{HASIL PENELITIAN DAN ANALISIS}

\section{A. Tolok Ukur Maqasid Syariah dalam Pengujian Undang-undang \\ Indonesia bukan negara Islam, tetapi Indonesia} merupakan negara muslim (Indonesia sebagai negara yang berpenduduk terbanyak beragama Islam). Sila ke-1 Pancasila yang berbunyi "Ketuhanan Yang Maha Esa" tersebut dapat dipahami sebagai nilai tauhid (ajaran Islam) dalam kehidupan berbangsa dan bernegara. Intinya bahwa di dalam nilai ketauhidan tersebut terdapat anjuran untuk untuk meyakini bahwa Allah SWT ikut berperan dalam kehidupan berbangsa dan bernegara melalui nilai-nilai ajaran ketauhidan dalam Islam. Misalnya demokasi Indonesia lebih menekankan pada prinsip persatuan dan kesatuan bangsa Indonesia, ide persatuan adalah suatu gagasan yang banyak diajarkan baik di dalam $\mathrm{Al}$ 
Qur'an maupun Sunnah Rasul, karena itu tujuan demokrasi adalah untuk kemaslahatan umum dan untuk memelihara persatuan dan kesatuan manusia.

Pandangan Muhammadiyah bahwa Negara Kesatuan Republik Indonesia (NKRI) yang diproklamasikan 17 Agustus 1945 adalah Negara Pancasila yang ditegakkan di atas falsafah kebangsaan yang luhur dan sejalan dengan ajaran Islam. Sila-sila yang terkandung dalam Pancasila secara esensi selaras dengan nilai-nilai ajaran Islam. Negara Pancasila yang mengandung jiwa, pikiran, dan cita-cita luhur sebagaimana termaktub dalam Pembukaan UUD 1945 itu dapat diaktualisasikan sebagai Baldatun Thayyibatun Wa Rabbun Ghafur yang berperikehidupan maju, adil, makmur, bermartabat, dan berdaulat dalam naungan ridla Allah SWT.

Berdasar pada Tanfidz Keputusan Muktamar Muhammadiyah Ke-47 menyebutkan bahwa Negara Pancasila sebagai Dâr Al-Ahdi Wa Al-Syahâdah, negara kesepakatan dan negara kesaksian. Dalam arti bahwa Muhammadiyah memiliki komitmen tinggi dengan negara pancasila dan siap bersama keluarga bangsa yang lain untuk mengisi negara pancasila untuk mencapai cita-cita nasional yang telah diletakkan oleh pendiri bangsa ini, yang di dalam Pembukaan UUD 45 berbunyi Negara Indonesia yang merdeka bersatu, berdaulat, adil, dan makmur. Muhammadiyah memberikan tafsir kontekstual terhadap cita-cita nasional ini, untuk menjadi Indonesia yang maju, adil, makmur, berdaulat dan bermartabat (Indonesia berkemajuan). Muhammadiyah berkomitmen untuk terus berjuang memproyeksikan Indonesia menjadi Negara Pancasila yang maju, adil, makmur, bermartabat, dan berdaulat dalam lindungan Allah SWT.

Negara Pancasila merupakan hasil konsensus nasional (dâr al-ahdi) dan tempat pembuktian atau kesaksian (dâr al-syahâdah) untuk menjadi negeri yang aman dan damai (dâr al-salâm). Negara ideal yang dicita-citakan Islam adalah negara yang diberkahi Allah karena penduduknya beriman dan bertaqwa (QS Al- A'raf: 96), beribadah dan memakmurkannya
(QS Al-Dzariyat: 56; Hud: 61), menjalankan fungsi kekhalifahan dan tidak membuat kerusakan di dalamnya (QS Al-Baqarah: 11, 30), memiliki relasi hubungan dengan Allah (hablun min Allâh) dan dengan sesama (hablun min al-nâs) yang harmonis (QS Ali Imran: 112), mengembangkan pergaulan antarkomponen bangsa dan kemanusiaan yang setara dan berkualitas taqwa (QS Al-Hujarat: 13), serta menjadi bangsa unggulan bermartabat (khairu ummah) (QS Ali Imran: 110).

Pancasila merupakan ideologi negara yang mengikat seluruh komponen bangsa dan negara, intinya Pancasila bukanlah agama dan bukan ideologi dalam kehidupan keagamaan, tetapi Pancasila merupakan ideologi negara yang fungsinya untuk menjalankan negara. Yang tentunya kandungan materi harus sejalan dengan nilai ajaran Islam, inilah yang menjadi dasar bahwa Pancasila itu Islami. Dalam Pancasila terkandung ciri keislaman dan keindonesiaan yang memadukan nilai-nilai ketuhanan dan kemanusiaan (humanisme religius), hubungan individu dan masyarakat, kerakyatan dan permusyawaratan, serta keadilan dan kemakmuran. Melalui proses integrasi keislaman dan keindonesiaan yang positif itu, umat Islam Indonesia sebagai kekuatan mayoritas dapat menjadi teladan yang baik (uswah hasanah) dalam mewujudkan cita-cita nasional yang sejalan dengan idealisasi Baldatun Thayyibatun wa Rabbun Ghafûr. Beberapa dasar Al-Qur'an yang membuktikan bahwa Pancasila mengandung nilainilai yang Islami: meliputi:

Tabel 1

Kesesuaian Nilai-nilai Pancasila dan Islam

\begin{tabular}{|l|l|}
\hline \multicolumn{1}{|c|}{$\begin{array}{c}\text { Sila dalam } \\
\text { Pancasila }\end{array}$} & \multicolumn{1}{|c|}{ Nilai-nilai dalam Al-Qur'an } \\
\hline $\begin{array}{l}\text { Ketuhanan Yang } \\
\text { Maha Esa }\end{array}$ & $\begin{array}{l}\text { Katakanlah: "Dialah Allah, Yang Maha } \\
\text { Esa (QS. Al Ikhlas ayat 1) }\end{array}$ \\
\hline $\begin{array}{l}\text { Kemanusiaan } \\
\text { yang Adil dan } \\
\text { Beradab }\end{array}$ & $\begin{array}{l}\text { "Wahai orang-orang yang beriman, } \\
\text { jadilah kamu orang yang benar-benar } \\
\text { penegak keadilan, menjadi saksi karena } \\
\text { Allah biarpun terhadap dirimu sendiri } \\
\text { atau ibu bapak dan kaum kerabatmu. } \\
\text { Jika ia kaya ataupun miskin, maka Allah } \\
\text { lebih tahu kemaslahatannya. Maka }\end{array}$ \\
\hline
\end{tabular}




\begin{tabular}{|c|c|}
\hline & $\begin{array}{l}\text { janganlah kamu mengikuti hawa nafsu } \\
\text { karena ingin menyimpang dari } \\
\text { kebenaran. Dan jika kamu memutar } \\
\text { balikkan (kata-kata) atau enggan } \\
\text { menjadi saksi, maka sesungguhnya Allah } \\
\text { adalah Maha Mengetahui segala apa } \\
\text { yang kamu kerjakan (QS An Nisa ayat } \\
\text { 135) }\end{array}$ \\
\hline $\begin{array}{l}\text { Persatuan } \\
\text { Indonesia }\end{array}$ & $\begin{array}{l}\text { "Hai manusia, sesungguhnya Kami } \\
\text { menciptakan kamu dari seorang laki-laki } \\
\text { dan seorang perempuan dan } \\
\text { menjadikan kamu berbangsa-bangsa } \\
\text { dan bersuku-suku supaya kamu saling } \\
\text { kenal-mengenal. Sesungguhnya orang } \\
\text { yang paling mulia diantara kamu disisi } \\
\text { Allah ialah orang yang paling takwa } \\
\text { diantara kamu. Sesungguhnya Allah } \\
\text { Maha Mengetahui lagi Maha Mengenal } \\
\text { (QS Al Hujurat ayat 13). }\end{array}$ \\
\hline $\begin{array}{l}\text { Kerakyatan yang } \\
\text { dipimpin oleh } \\
\text { Hikmat } \\
\text { Kebijaksanaan } \\
\text { dalam } \\
\text { Permusyawaratan } \\
\text { Perwakilan }\end{array}$ & $\begin{array}{l}\text { "Dan (bagi) orang-orang yang menerima } \\
\text { (mematuhi) seruan Tuhannya dan } \\
\text { mendirikan shalat, sedang urusan } \\
\text { mereka (diputuskan) dengan } \\
\text { musyawarah antara mereka, dan } \\
\text { mereka menafkahkan sebagian dari } \\
\text { rezeki yang Kami berikan kepada mereka } \\
\text { (QS Asy Syuro ayat 38). }\end{array}$ \\
\hline $\begin{array}{l}\text { Keadilan Sosial } \\
\text { bagi Seluruh } \\
\text { Rakyat Indonesia }\end{array}$ & $\begin{array}{l}\text { "Sesungguhnya Allah menyuruh (kamu) } \\
\text { berlaku adil dan berbuat kebajikan, } \\
\text { memberi kepada kaum kerabat, dan } \\
\text { Allah melarang dari perbuatan keji, } \\
\text { kemungkaran dan permusuhan. Dia } \\
\text { memberi pengajaran kepadamu agar } \\
\text { kamu dapat mengambil pelajaran (QS An } \\
\text { Nahl ayat 90). }\end{array}$ \\
\hline
\end{tabular}

Selain itu, berdasarkan telaah Sahal Mahfudh, bahwa mengacu pada fakta sosiologis Indonesia memiliki mayoritas umat Islam, maka harus ada kebutuhan mutlak mengenai nilai-nilai dasar dan konsep-konsep utama dalam UUD 1945 bisa diterima dengan sepenuh hati oleh umat Islam. Sebab dengan cara ini umat Islam akan bersedia memikul tangungjawab kebangsaan dan kenegaraan dengan sepenuh hati (Mas'udi, 2013: xxx) dengan keyakinan bahwa memperjuangan terwujudnya cita-cita nasional dalam UUD 1945 (staatsidee dan rechtsidee) sejalan dengan mewujudkan pesan-pesan yang diajarkan dalam Islam (maqashid syari'ah). Untuk itu, idealnya ajaran Syari'ah Islam harus mewarnai konstitusionalisme Indonesia yang kemudian dituangkan dalam UUD 1945.
Mahfud MD, menilai dasar negara Pancasila dan UUD 1945 adalah negara yang Islami, tetapi bukan negara Islam. Negara Islami merupakan negara yang dalam konstruksinya mengandung nilai ajaran Islam (substantif), dan secara resmi tidak menggunakan simbol Islam. Beberapa ajaran Islam yang terkandung dalam kehidupan bernegara adalah kepemimpinan yang adil, amanah, demokratis, menghormati hak asasi manusia, dan sebagainya. Pilihan ini dilandasi beberapa argumentasi: (1) di dalam al-Qur'an dan sunnah tidak ada keharusan bagi umat Islam untuk membentuk negara Islam, tetapi harus ada jaminan perlindungan negara terhadap kebebasan untuk menjalankan ajaran Islam. Kedua, tokoh-tokoh umat Islam pada masa lalu sudah memperjuangkan melalui jalur konstitusional dan demokratis untuk menawarkan agar Indonesia dibangun dengan dasar Islam, tetapi hasil kesepakatan bangsa yang diperoleh dari pergumulan politik yang juga demokratis adalah membangun Indonesia sebagai negara kabangsaan yang berdasarkan Pancasila (Mas'udi, 2013: xix)

Bahkan buku berjudul "syarah UUD 1945 Perspektif Islam” karya Masdar Farid Mas'udi memberikan uraian bahwa setiap teks (pembukaan dan pasal-pasal) dalam UUD 1945 memiliki landasan/ rujukan nash dalam al-Qur'an dan sunnah. Intinya yang terpenting adalah membangun realisasi nilai ajaran konstitusionalisme Islam kedalam kehidupan berbangsa dan bernegara menurut dasar Pancasila disegala bidang, misalnya bidang perbankan, dan lainnya. Artinya bahwa secara substantif Pancasila dan UUD 1945 mengandung ajaran Islam, yang dalam konteks konstitusi dapat disepadankan dengan pemahaman konstitusi syariah.

Konstitusi syari'ah artinya kandungan konstitusi sebuah negara memuat materi Syariah Islam, sehingga tergambar Syariah Islam secara komprehensif (kāmil dan syāmil), meskipun dengan redaksi yang sangat global dan ringkas disitulah sebenarnya manhaj penerapan Syariah Islam dalam berbagai bidang dipaparkan. Dalam arti bisa saja sebuah konstitusi menggunakan bahasa Indonesia ataupun bahasa sah 
negara lainnya (Inggris, dll), namun materi muatan konstitusi tetap harus sejalan dengan nilai-nilai syari'ah Islam. Jika merujuk kondisi ini tentu Indonesia memiliki konstitusi syariah pula, sebab setiap teks (pembukaan dan pasal-pasal) dalam UUD 1945 memiliki landasan nash dalam al-Qur'an dan sunnah yang jelas sehinga realisasinya membutuhkan sikap yang sungguh-sungguh dan penuh tanggungjawan dari umat Islam.

Oleh karena itu, mengingat bahwa UUD 1945 merupakan konstitusi Islami, maka tidak perlu diperdebatkan lagi mengenai nilai ajaran Islam dalam negara Pancasila, sebab Pancasila dan UUD 1945 adalah pedoman negara yang sesuai dengan ajaran Islam (bahkan kandungan materinya berasal dari nilai-nilai ajaran Islam). Untuk itu, misi hidup seorang muslim Indonesia adalah beribadah kepada Allah dengan sebaik-baiknya, dan sejatinya bahwa berdirinya sebuah negara dengan segenap struktur dan kewenangannya dalam pandangan Islam agar tetap bertujuan untuk mensukseskan penerapan syariah (maqashid syari'ah) (Nur Rohim Yunus, 2015: 267-268). Penerapan dan formalisasi Siyasah Syari'ah (maqashid syari'ah) dapat dilakukan melalui berbagai kebijakan negara, baik oleh eksekutif, legislatif maupun yudikatif, baik melalui bentuk produk hukum (peraturan perundang-undangan) maupun putusan peradilan. Salah satunya tentu dilakukan oleh Mahkamah Konstitusi yang memiliki fungsi untuk mengawal (to guard) konstitusi, agar dilaksanakan dan dihormati baik penyelenggara kekuasaan negara maupun warga negara, sebagai penafsir akhir konstitusi (interpreter) dan pelindung (protector) konstitusi.

Menurut Jimly Asshiddiqie menguraikan bahwa "dalam konteks ketatanegaraan, MK dikontruksikan sebagai pengawal konstitusi yang berfungsi menegakkan keadilan konstitusional ditengah masyarakat, MK bertugas mendorong dan menjamin agar konstitusi dihormati dan dilaksanakan oleh semua komponen negara secara konsisten dan bertanggung jawab, ditengah kelemahan sistem konstitusi yang ada MK berperan sebagai penafsir agar spirit konstitusi selalu hidup dan mewarnai keberlangsungan bernegara dan bermasyarakat". Fungsi MK yaitu sebagai pengawal konstitusi, penafsir konstitusi juga adalah pengawal, artinya bahwa dalam konteks ini MK juga menjadi pengawal ajaran Islam, penafsir syariah Islam dalam kehidupan bernegara agar terselenggaranya pemerintahan negara yang stabil

Dalam konteks penerapan maqashid syari'ah, MK secara secara substantif mewujudkan maqashid syari'ah. Pandangan Jimly Asshiddiqie (2006:7) bahwa untuk menilai dan menguji konstitusionalitas suatu undang-undang dapat mempergunakan beberapa alat ukur atau penilai yaitu: (1) Naskah UUD resmi tertulis; (2) Dokumen-dokumen tertulis yang terkait erat dengan naskah UUD itu seperti risalah- risalah, keputusan dan ketetapan MPR, undang-undang tertentu, peraturan tata tertib, dll; (3) Nilai- nilai konstitusi yang hidup dalam praktek ketatanegaraan yang telah dianggap sebagai bagian yang tak terpisahkan dari keharusan dan kebiasaan dalam penyelenggraan kegiatan bernegara; (4) Nilai- nilai yang hidup dari kesadaran kognitif rakyat serta kenyataan prilaku politik dan hukum warga negara yang dianggap sebagai kebiasaan dan keharusan yang ideal dalam peri kehidupan berbangsa dan bernegara. Merujuk pada pandangan tersebut, selain Pancasila dan UUD yang mengandung nilai-nilai Islam, juga tolok ukur nilai-nilai Islam dapat diterapkan sebagai tolok ukur dalam pengujian undang-undang, karena nilai-nilai Islam termasuk ke dalam nilai-nilai konstitusi dan nilai-nilai yang hidup di masyarakat.

Intinya bahwa maqashid syari'ah merupakan cita hukum masyarakat muslim Indonesia, artinya harapan umat Islam di Indonesia adalah mewujudkan cita hukum tersebut dalam bentuk berbagai kebijakan yang ada, namun tetap dalam kerangka bernegara hukum Pancasila. Maqashid syariah merupakan bintang pemandu bagi umat muslim yang berimplikasi pada keharusan pembentukan hukum, pelaksanaan hukum, dan 
penegakan huku nasional bertujuan untuk mencapai ide-ide dalam maqashid syariah, atau sejalan dan tidak bertentangan dengan maqashid syariah. Maqashid syari'ah bertujuan untuk memelihara kemaslahatan agama/ din, memelihara kemaslahatan jiwa/ nafs, memelihara kemaslahatan akal/ aql, memelihara kemaslahatan keturunan/ nasl, dan memelihara kemaslahatan harta/ mal) (Ali Imron, 2015: 51).

Mengingat bahwa Pancasila dan UUD 1945 merupakan produk yang Islami dan mayoritas masyarakat Indonesia juga beragama Islam, maka MK baik kelembagaan/ personal hakimnya memiliki hubungan yang erat (sosiologis) dengan ajaran Islam dan maqashid syari'ah. MK dapat memberikan konstruksi nilai-nilai Islam yang sejalan dengan konstruksi "Negara Pancasila sebagai Darul Ahdi Wa Syahadah". Para hakim MK tidak secara tradisional dididik untuk melaksanakan ijtihad (penemuan hukum melalui tafsir konstitusi). Akibatnya, metode hibrida telah diadopsi oleh MK untuk mengakomodasi otoritas sumber tekstual hukum Islam di Indonesia yang berbilang. Putusan MK, karenanya, berisi instrumen hukum Islam yang merefleksikan penghormatan para hakim terhadap norma hukum Islam dan transformasi prinsip-prinsip Syariah dalam kerangka penegakan HAM. Dalam prosesnya, MK menyatakan dirinya tidak terikat oleh para pelaku hukum Islam dan pendapat mereka tentang penafsiran hukum Islam mana yang absah. Hal ini disebabkan MK menetapkan dirinya memiliki kuasa untuk menafsirkan dan membatasi hukum Islam yang dalam pandangannya sesuai dengan agenda negara (seperti penegakan HAM). Meskipun begitu, MK masih menggunakan konsep dan prinsip hukum dalam hukum Islam untuk membenarkan putusannya masih berada dalam batasan Islam. Oleh karena itu, putusan MK masuk ke dalam ruang lingkup siyasah syar`iyyah, paling tidak berdasarkan konsep modern siyasah syar ‘ iyyah yang dikembangkan oleh Abd al-Razzaq al-Sanhuri, dan penafsiran MK terhadap norma hukum Islam mana yang berlaku di Indonesia bisa dijustifikasi berdasarkan konsep siyasah syar `iyyah juga (Al Fitri, 2014: 312). Dalam praktek pengujian undnag-undang penerapan maqashid syari'ah, misalnya dalam beberpa putusan berikut: Putusan MK No.2-3/PUU-V/2007 perihal Pengujian Undang-undang No.22 Tahun 1997 tentang Narkotika terhadap UUD 1945 perihal pidana mati, Putusan MK No.12/PUU-V/2007 perihal poligami, Putusan MK No.68/PUU-XII/2014 perihal Pengujian Undang-undang No.1 Tahun 1974 tentang Perkawinan (perihal perkawinan beda agama), putusan MK No.85/PUU-XI/2013 perihal pengujian undang-undang No.7 Tahun 2004 tentang Sumber Daya Air (UU SDA).

\section{B. Implikasi Maqashid Syariah dalam Putusan Pengujian Undang-undang \\ MK sebagai lembaga negara yang menjaga} Pancasila dan UUD 1945 memiliki peranan strategis dalam mewujudkan cita hukum (rechtsidee) dan cita negara (stattsidee), namun MK dalam putusan pengujian undang-undang memaknai cita hukum dan cita negara tersebut secara general (termasuk di dalamnya maqashid syari'ah). Berkaitan dengan maqashid syari'ah, tentu MK dalam setiap putusannya tidak selalu mengutamakan maqashid syari'ah secara komprehensif, namun karena nilai-nilai Pancasila sejalan dengan nilai-nilai Islam (Pancasila sebagai ideologi yang Islami), maka banyak dijumpai putusan MK yang justru menggunakan dalil-dalil Islami sebagai bangunan argumentasi (termasuk di dalamnya penafsiran nilai-nilai Islam yang sejalan dengan nilainilai Pancasila).

Dalam konteks fungsi, bahwa fungsi MK: (1) MK sebagai pengawal konstitusi (the Guardian of the Constitution); (2) MK sebagai pengendali keputusan berdasarkan sistem demokrasi (Control of Democracy); (3) MK sebagai penafsir konstitusi (the Sole or the Highest Interpreter of the Constitution); (4) MK sebagai pelindung hak konstitutional warga negara (the Protector of the Citizens' Constitutional Rights); (5) MK sebagai pelindung hak asasi manusia (the Protector of 
Human Rights) adalah fungsi yang senada dengan mewujudkan maqashid syari'ah bertujuan untuk memelihara kemaslahatan agama/ din, memelihara kemaslahatan jiwa/ nafs, memelihara kemaslahatan akal/ aql, memelihara kemaslahatan keturunan/ nasl, dan memelihara kemaslahatan harta/ mal). Untuk mengkaji apakah pengujian undang-undang oleh Mahkamah Konstitusi dalam menerapkan maqashid syari'ah harus melakukan upaya penelaahan terhadap putusan-putusan MK terkait pengujian undangundang, yang didalamnya terdapat tolok ukur (dasar pertimbangan/ bangunan argumentasi yuridis).

Berikut beberapa putusan yang berkaitan dengan penggunaan tolok ukur maqashid syari'ah dalam putusan pengujian undang-undang:

\section{Putusan MK Perihal Pidana Mati}

Putusan MK No.2-3/PUU-V/2007 perihal Pengujian Undang-undang No.22 Tahun 1997 tentang Narkotika terhadap UUD 1945. Amar putusan menyatakan menolak permohonan bahwa dalam konteks substansi hukum (norma hukum), "ketentuan Pasal 80 ayat (1) huruf a, ayat (2) huruf a, ayat (3) huruf a; Pasal 81 ayat (3) huruf a; Pasal 82 ayat (1) huruf a, ayat (2) huruf a, dan ayat (3) huruf a dalam UU Narkotika, sepanjang yang mengenai ancaman pidana mati, tidak bertentangan dengan Pasal 28A dan Pasal 28I ayat (1) UUD 1945. Dalam pengujian ini, pemohon menggunakan ketentuanketentuan dalam UU Narkotika sebagai pintu masuk pengajuan permohonan pengujian undang-undang terhadap UUD 1945, tujuan akhir yang hendak dicapai adalah hapusnya pidana mati dalam seluruh ketentuan perundang-undangan Indonesia.

Jika merujuk pada pandangan MK tersebut, bahwa hukuman mati tidak bertentangan dengan UUD 1945, artinya tafsir konstitusional Pasal 28I ayat (1) "Hak untuk hidup, hak untuk tidak disiksa, hak kemerdekaan pikiran dan hati nurani, hak beragama, hak untuk tidak diperbudak, hak untuk diakui sebagai pribadi di hadapan hukum, dan hak untuk tidak dituntut atas dasar hukum yang berlaku surut adalah hak asasi manusia yang tidak dapat dikurangi dalam keadaan apa pun”. Artinya bahwa hukuman mati dalam UU Narkotika tidak bertentangan dengan hak hidup yang dijamin UUD 1945 lantaran jaminan hak asasi manusia dalam UUD 1945 tidak menganut asas kemutlakan.

Hal yang menarik untuk ditelaah terkait penggunaan tolok ukur maqashid syari'ah dalam pengujian undang-undang adalah, bangunan argumentasi MK bahwa Indonesia sebagai negara dengan penduduk muslim terbesar di dunia dan juga anggota Organisasi Konferensi Islam (OKI) secara moral perlu memperhatikan isi Deklarasi Cairo Mengenai Hak-hak Asasi Islami yang diselenggarakan oleh OKI yang dalam Pasal 8 huruf a deklarasi tersebut menyatakan, "Kehidupan adalah berkah Tuhan dan hak untuk hidup dijamin bagi setiap umat manusia. Adalah tugas dari individu, masyarakat dan negara-negara untuk melindungi hak-hak ini dari setiap pelanggaran apa pun, dan dilarang untuk mencabut kehidupan kecuali berdasarkan syariat". Sehingga, menurut pandangan negara-negara anggota OKI, pencabutan hak untuk hidup yang tidak didasarkan atas hukum yang bersumber dari syariat itulah yang dilarang. Artinya bahwa putusan MK ini sejalan dengan jaminan hak hidup dalam Islam, dimana hak hidup dapat dicabut oleh pengadilan dengan alasan syari'ah dan tidak boleh mencabut hak hidup yang tidak berdasarkan syari'ah. Artinya bahwa pelaku kejahatan kriminal (narkoba) dapat dijatuhi hukuman mati, dalam perspektif syariah bahwa kejahatan narkoba merupakan tindakan yang merusak kehidupan berbangsa dan bernegara, merusak pikiran, kemiskinan, kesehatan (ganguan mental), dan bisa jadi berdampak pada kerusakan lainnya (pembunuhan, dan lainnya

Menurut Yunahar Ilyas bahwa penerapan hukuman mati bagi pengedar narkotika dinilai tepat. Alasannya, narkotika memiliki daya rusak yang besar, pengedar narkotika sebagai perbuatan fasad (merusak). "Perbuatan fasad ini maksudnya perbuatan merusak dan efeknya tidak baiknya bagi orang banyak". Kategori fasad, artinya narkotika dapat 
merusak dan membunuh hingga ratusan ribu jiwa dan kondisi ini lebih parah dari pembunuhan biasa. Yunahar menyebutkan dalam Islam ada dua kategori terkait perbuatan fasad (fasad secara pribadi dan fasad secara kelompok). “ Kalau fasad-nya dilakukan pribadi bisa dihukum mati sedangkan kalau fasad dilakukan oleh kelompok maka wajid diperangi”. Namun hukuman mati ini jangan sampai menunda-nunda eksekusi, jika sudah dihukum mati yang langsung eksekusi setelah memiliki kekuatan hukum tetap (inkracht) ("Soal Hukuman Mati, Ini Pendapat Muhammadiyah", http://www.republika.co.id/ berita/dunia-islam/islam-nusantara/15/01/19/ nieysmsoal-hukuman-mati-ini-pendapat muhammadiyah, diunduh tanggal 1 Oktober 2017, pukul 21.00).

Hukuman mati terhadap kasus narkotika ini dapat dibenarkan menurut maqashid syariah, dikarenakan bahaya narkotika bersifat massif dalam merusak sendi-sendi kehidupan bernegara, yang saat ini jumlah korban sangat banyak. Artinya perilaku pengedar narkotika telah merusak maqashid syariah, dan hukuman mati telah sesuai dengan maqashid syari'ah, yakni hukuman mati bertujuan untuk memelihara kemaslahatan agama/ din, memelihara kemaslahatan jiwa/ nafs, memelihara kemaslahatan akal/ aql, memelihara kemaslahatan keturunan/ nasl, dan memelihara kemaslahatan harta/ mal) dari bahaya narkotika.

Disisi lain, penulis sependapat dengan putusan MK yang memperhatikan sifat irrevocable dalam pidana mati, artinya perumusan, penerapan, maupun pelaksanaan pidana mati dalam berbagai kasus hendaklah memperhatikan ketentuan berikut:

a. pidana mati bukan lagi merupakan pidana pokok, melainkan sebagai pidana yang bersifat khusus dan alternatif;

b. pidana mati dapat dijatuhkan dengan masa percobaan selama sepuluh tahun yang apabila terpidana berkelakuan terpuji dapat diubah dengan pidana penjara seumur hidup atau selama 20 tahun; c. pidana mati tidak dapat dijatuhkan terhadap anak-anak yang belum dewasa;

d. eksekusi pidana mati terhadap perempuan hamil dan seseorang yang sakit jiwa ditangguhkan sampai perempuan hamil tersebut melahirkan dan terpidana yang sakit jiwa tersebut sembuh.

2. Putusan MK Perihal Poligami dan Perkawinan Beda Agama

a. Putusan MK No.12/PUU-V/2007

UU Nomor 1 Tahun 1974 tentang Perkawinan yang menyatakan bahwa asas perkawinan adalah monogami, dan poligami diperbolehkan dengan alasan, syarat, dan prosedur tertentu tidak bertentangan dengan ajaran Islam; tidak bertentangan dengan hak untuk membentuk keluarga, hak untuk bebas memeluk agama, dan beribadat menurut agamanya, hak untuk bebas dari perlakuan yang bersifat diskriminatif sebagaimana diatur dalam Pasal 28B Ayat (1), Pasal 28E Ayat (1), Pasal 28I Ayat (1), dan Ayat (2), serta Pasal 29 Ayat (1) dan Ayat (2) UUD 1945.

Pendapat MK dalam putusan tersebut bahwa: adanya ketentuan yang mengatur tentang poligami untuk WNI yang hukum agamanya memperkenankan perkawinan poligami adalah wajar, oleh karena sahnya suatu perkawinan menurut Pasal 2 Ayat (1) UU Perkawinan apabila dilakukan sesuai dengan agama dan kepercayaannya. Selain itu, pasalpasal yang tercantum dalam UU Perkawinan yang memuat alasan, syarat, dan prosedur poligami, sesungguhnya semata-mata sebagai upaya untuk menjamin dapat dipenuhinya hak-hak isteri dan calon isteri yang menjadi kewajiban suami yang berpoligami dalam rangka mewujudkan tujuan perkawinan. Dengan demikian, hal dimaksud tidak dapat diartikan meniadakan ketentuan yang memperbolehkan perkawinan poligami.

Permohonan ini ditolak karena MK berpendapat bahwa monogami adalah asas perkawinan dalam UU Perkawinan No.1 Tahun 1974, poligami diizinkan hanya jika permohonan untuk itu memenuhi 
ketentuan yang tidak tidak bertentangan dengan ajaran Islam. Dalam menyusun argumennya, MK merujuk pada penafsiran hukum perkawinan Islam yang diberika oleh para saksi ahli dari pihak pemerintah. Menurut para saks ahli ini, poligami tidak masuk dalam kategori ibadah dalam syariah; poligami termasuk dalam aspek hubungan kemasyarakatan (mu'amalat) dalam syariah dan status hukum asalnya adalah boleh (mubah). Karena hukum dasar poligami adalah mubah, ketentuan pembatasan poligami dalam UU Perkawinan No. 1 Tahun 1974 tidak bertentangan dengan klausa kebebasan beragama dalam UUD 1945. Tidak melalukan poligami, tidak merupakan pelanggaran terhadap kewajiban Islam di bidang ibadah. Bahkan ketentuan pembatasan poligami dalam UU Perkawinan No. 1 Tahun 1974 bisa menjamin bahwa prinsip keadilan yang disyaratkan dari perkawinan poligami akan dipatuhi oleh para pemohon.

Keadilan dalam perkawinan poligami ditafsirkan oleh MK dengan kemampuan untuk menyediakan nafkah untuk para istri dan anak, serta kemampuan untuk membagi waktu untuk seluruh rumah tangganya. Menurut MK, merupakan kewajiban negara lewat hukum dan sistem peradilannya untuk menjamin terwujudnya keadilan bagi para pihak yang terkena dampak poligami, terutama perempuan dan anak-anak. Pembatasan poligami dalam UU Perkawinan No. 1/1974 justru sejalan dengan tujuan perkawinan di Indonesia, yakni untuk membentuk sebuah keluarga yang sakinah, mawaddah, dan rahmah. Mahkamah Konstitusi juga membenarkan otoritas negara untuk mengatur Islam di Indonesia, dan kewajiban negara untuk mengatur aspek hukum yang mewujudkan keadilan, termasuk disini membatasi praktek poligami. Dengan hal ini berarti kebijakan pemerintah sesuai dengan ilmu hukum Islam (fikih). Dalam argumennya, MK kemudian mengutip bahwa atas dasar kepentingan umum, negara memilik otoritas untuk menentukan ketentuan-ketentuan hukum yang harus ditaati oleh warga negaranya yang ingin melaksanakan poligami.
Ini terutama dimaksudkan untuk mencapai tujuan perkawinan yakni terciptanya keluarga yang bahagia, kekal berdasarkan Ketuhanan yang Maha Esa (Alfitri, 2014: 304). Putusan MK terkait dengan pembatasan poligami dalam UU Perkawinan No. 1 Tahun 1974 bertujuan untuk memelihara kemaslahatan agama/ din, memelihara kemaslahatan jiwa/ nafs, memelihara kemaslahatan keturunan/nasl, termasuk kemaslahanan harta/ mal.

\section{b. Putusan MK No.68/PUU-XII/2014}

Putusan MK No.68/PUU-XII/2014 perihal Pengujian Undang-undang No.1 Tahun 1974 tentang Perkawinan, pengujian ini bertujuan agar perkawinan beda agama yang terhalang dengan berlakunya Pasal 2 ayat (1) "Perkawinan adalah sah apabila dilakukan menurut hukum masing-masing agama dan kepercayaannya itu" dapat dinyatakan konstitusional menurut UUD 1945. Namun putusan MK menyatakan bahwa Pasal 2 ayat (1) telah sesuai dan tidak bertentangan dengan Pancasila dan UUD 1945, sehingga tidak memberikan ruang bagi perkawinan beda agama.

Beberapa argumentasi MK, meliputi: (1) Prinsip Ketuhanan yang terkandung di dalam UUD 1945 merupakan perwujudan dari nilai-nilai ajaran Islam, salah satunya adalah perihal perkawinan. Perkawinan bagi umat Islam merupakan hak konstitusional yang harus dihormati dan dilindungi oleh negara, namun pengaturan hak tersebut merupakan kewenangan negara; (2) diaturnya hak konstitusional dalam bidang perkawinan tersebut bertujuan untuk menjamin pengakuan dan penghormatan atas hak dan kebebasan orang lain, serta untuk memenuhi tuntutan yang adil sesuai dengan pertimbangan moral, nilai-nilai agama, keamanan, dan ketertiban umum dalam suatu masyarakat demokratis.

Menurut MK bahwa dalam kehidupan berbangsa dan bernegara berdasarkan Pancasila dan UUD 1945, agama menjadi landasan dan negara mempunyai kepentingan dalam hal perkawinan. Agama menjadi landasan bagi komunitas individu yang menjadi wadah kebersamaan pribadi-pribadi 
dalam hubungannya dengan Tuhan Yang Maha Esa serta turut bertangungjawab terwujudnya kehendak Tuhan Yang Maha Esa untuk meneruskan dan menjamin kerbelangsungan hidup manusia. Negara juga berperan memberikan pedoman untuk menjamin kepastian hukum kehidupan bersama dalam tali ikatan perkawinan yang sah yang merupakan wujud dan jaminan keberlangsungan hidup manusia. Perkawinan tidak boleh hanya dilihat dari aspek formal semata, tetapi juga harus dilihat dari aspek spiritual dan sosial. Agama menetapkan keabsahan perkawinan sedangkan undang-undang menentapkan keabsahan administratif yang dilalukan negara.

Pandangan Islam terhadap perkawinan beda agama, pada prinsipnya tidak memperkenankannya. Dalam al-Qur'an dengan tegas dilarang perkawinan antara orang Islam dengan orang musyrik seperti yang tertulis dalam surat al- Baqarah ayat 221: "Dan janganlah kamu menikahi wanita-wanita musyrik, sebelum mereka beriman. Sesungguhnya wanita budak yang mukmin lebih baik dari wanita musyrik, walaupun dia menarik hatimu. dan janganlah kamu menikahkan orang-orang musyrik (dengan wanitawanita mukmin) sebelum mereka beriman. Sesungguhnya budak yang mukmin lebih baik dari orang musyrik, walaupun dia menarik hatimu. mereka mengajak ke neraka, sedang Allah mengajak ke surga dan ampunan dengan izin-Nya. dan Allah menerangkan ayat-ayat-Nya (perintah-perintah-Nya) kepada manusia supaya mereka mengambil pelajaran".

Larangan perkawinan dalam surat al-Baqarah ayat 221 itu berlaku baik bagi laki-laki maupun wanita yang beragama Islam untuk kawin dengan orang-orang yang tidak beragama Islam. Atau dengan kata lain dapat dikatakan bahwa mereka yang tidak beragama Islam itu musyrik. Akan tetapi seorang lakilaki muslim boleh menikah dengan wanita (Ahli Kitab) dengan dasar surat Al- Ma'idah ayat 5. Pandangan Yusuf Qardlowi terkait hal ini adalah bahwa kebolehan nikah dengan wanita kitabiyah adalah tidak mutlak, tetapi terikat dengan ikatanikatan yang harus diperhatikan, yaitu sebagai berikut: pertama, wanita kitabiyah benar-benar berpegang pada ajaran agama samawi, tidak ateis, tidak murtad, dan tidak beragama selain agama samawi. Kedua, wanita Kitabiyah tersebut harus mukhsonat (memelihara kehormatan dirinya dari perbuatan zina), dan ketiga, bukan wanita Kitabiyah yang kaumnya berstatus musuh dengan kaum muslimin.

Putusan MK yang menolak gugatan pelarangan perkawinan beda agama dan mengembalikan keabsahan perkawinan menurut UU No.1 Tahun 1974, dan larangan perkawinan beda agam ini telah sesuai dengan landasan falsafah Pancasila dan UUD 1945, menurut MK bahwa UU No.1 Tahun 1974 telah dapat mewujudkan prinsip-prinsip yang terkandung dalam Pancasila dan UUD 1945 serta telah dapat pula menampung segala kenyataan yang hidup dalam masyarakat. Dalam konteks maqashid syariah bahwa putusan MK bertujuan untuk memelihara memelihara kemaslahatan agama/ din dan memelihara kemaslahatan keturunan/ nas. Sebab segala tindakan dan perbuatan yang dilakukan oleh warga negara Indonesia termasuk dalam hal menyangkut perkawinan harus taat dan tunduk serta tidak bertentangan dengan ajaran Islam.

\section{Putusan MK No.85/PUU-XI/2013}

Putusan MK No.85/PUU-XI/2013 perihal pengujian undang-undang No.7 Tahun 2004 tentang Sumber Daya Air (UU SDA) ini merupakan bukti nyata pelembagaan green constitution dengan basis nilai-nilai maqashid syariah. Dalam pengujian ini, MK membatalkan keberlakuan secara keseluruhan UU SDA karena tidak memenuhi prinsip dasar pembatasan pengelolaan sumber daya air. Dalam putusannya MK menyatakan bahwa air harus dikuasai negara karena kebutuhan terhadap air merupakan kebutuhan hidup orang banyak yang sesuai dengan Pasal 33 ayat (2) dan ayat (3) UUD 1945. Sehingga, dalam pengusahaan air harus ada pembatasan ketat sebagai upaya menjaga kelestarian 
dan ketersediaan air bagi kehidupan. Dalam putusan tersebut, secara jelas bahwa green constitution menjadi tolok ukur dalam pengujian undang-undang, tolok ukur merupakan sesuatu yang dipakai sebagai dasar, standar, atau patokan dalam mengukur dan menilai sesuatu. Jika dikaitkan dengan pengujian undangundang, tolok ukur dapat diartikan sebagai dasar, standar, atau patokan dalam mengukur dan menilai pertentangan norma UU SDA terhadap UUD 1945.

Tolok ukur green constitution ini setidaknya terlihat dari beberapa pembatasan dalam pengelolaan sumber daya air, yaitu: pertama, setiap pengusahaan air tidak boleh mengganggu, mengesampingkan, apalagi meniadakan hak rakyat, sebab pengelolaan air dikuasai negara, air ditujukan untuk sebesar-besarnya kemakmuran rakyat; kedua, negara harus memenuhi hak rakyat atas air sebagai salah satu hak asasi manusia, yang berdasarkan Pasal 28I ayat (4) UUD "Perlindungan, pemajuan, penegakan, dan pemenuhan hak asasi manusia adalah tanggung jawab negara, terutama pemerintah" harus menjadi tanggung jawab pemerintah; ketiga, pengelolaan air pun harus mengingat kelestarian lingkungan, sesuai dengan Pasal 28H ayat (1) "Setiap orang berhak hidup sejahtera lahir dan batin, bertempat tinggal, dan mendapatkan lingkungan hidup yang baik dan sehat serta berhak memperoleh pelayanan kesehatan"; keempat, air merupakan sumber daya yang menjadi kebutuhan rakyat banyak menurut Pasal 33 ayat 2 UUD 1945 "Cabang-cabang produksi yang penting bagi negara dan yang menguasai hajat hidup orang banyak dikuasai oleh negara”, untuk itu perlu adanya pengawasan dan pengendalian oleh negara secara mutlak, namun masyarakat tetap harus melakukan pengawasan berkaitan dengan fungsi negara tersebut; Kelima, prioritas yang paling utama adalah pengusahaan atas air adalah BUMN atau BUMD yang bertanggungjawab untuk kemaslahatan umat/ menjamin ketersediaan air bagi rakyat. "Apabila semua pembatasan tersebut terpenuhi dan masih ada ketersediaan air, pemerintah masih dimungkinkan memberi izin pada swasta untuk melakukan pengusahaan atas air dengan syarat-syarat tertentu.

Menurut Al-Qur'an menekankan bahwa pentingnya air dalam kehidupan dengan menyebutnya berkali-kali dalam pelbagai tempat (dunia modern mengenalnya dengan istilah green constitution). Al-Quran menyebut air dengan istilah $m \bar{a}$ ' atau al-mā' yang berarti cairan yang berwarna bening dan tembus pandang. Al-Quran menyebut dua kata tersebut sebanyak 60 kali dalam berbagai konteks. Di samping itu, kata-kata lain yang disebutkan al-Quran terkait dengan makna air adalah al-mațar, al-anhār, dan al'uyun. Tiga suku kata tersebut disebutkan oleh al- Quran sebanyak 214 kali. Banyaknya penyebutan al-Quran terhadap "air" sebanding dengan makna air yang sangat penting bagi kehidupan, selain sebagai isyarat keharusan memerhatikan, meneliti, dan mengkajinya (Sukarni, 2014: 116). Dalam kaidah ilmu tafsir bahwa penyebutan entitas berkali-kali dalam Al-Qur'an menunjukkan tingkat urgensi entitas tersebut dalam kehidupan dan menuntut manusia memberikan perhatian serius terhadapnya. Manusia dan dan semua makhluk hidup lainnya tidak dapat bertahan hidup tanpa air. Hal itu lantaran air menjadi salah satu sumber kehidupan yang amat esensial. Di dalam Al-Qur'an dikatakan "Dan dari air Kami (Allah) jadikan segala sesuatu yang hidup” (QS. 21:30). Artinya segala makhluk hidup sangat tergantung kepada air.

Artinya putusan MK diatas berkaitan dengan pengelolaan air telah sesuai dengan maqashid syari'ah, sebab perlu dibangun kesadaran dan tanggungjawab bersama tentang permasalahan air yang meliputi bagaimana pandangan tentang air, pemanfaatannya, konservasi dan kelestariannya, pengelolaannya, dan mencukupi ketersediaan air bersih secara adil bagi seluruh masyarakat. Berkaitan dengan maqashid syari'ah menunjukkan bahwa putusan MK tersebut bertujuan untuk: memelihara kemaslahatan jiwa/ nafs, sebab air merupan hal yang daruriyyat, selain itu memelihara harta bersama (air) dari kerusakan. 
Air merupakan benda yang sangat diperlukan dalam kehidupan, baik sebagai alat bersuci, pengairan tanaman, maupun untuk pemenuhan keperluan konsumsi manusia dan hewan, air menjadi benda milik bersama sebagaimana padang rumput dan api. Oleh karena itu, air yang yang berada di tempattempat umum/ tidak dimiliki oleh seseorang atau kelompok tertentu, seperti laut, sungai, danau dan lain-lain, semua orang memiliki hak yang sama untuk memanfaatkannya dan kewajiban yang sama untuk memeliharanya. Ketetapan hukum fiqih ini berdasar hadis riwayat Ibnu Majah dan Abi Daud tentang air, padang rumput, dan api, sebagai benda sosial milik bersama (Sukarni, 2014: 125) (dikuasai negara: peneliti). Implikasi dari hadits yang terhadap sumber daya air adalah: pertama, bahwa setiap mahluk yang bernyawa (terutama manusia) memiliki hak untuk mengakses/ menikmati air dalam kehidupannya, kedua setiap orang yang menjalankan maqhashid syariah harus memiliki pandangan, kewajiban dan tanggungjawab yang sama untuk menjaga, memelihara, menggunakan sesuai dengan kebutuhannya (hemat), dan tidak boleh melakukan mudharat terhadap penggunaan air, karena ada hak bagi generasi selanjutnya. ketiga, setiap masyarakat Indonesia memiliki kewajiban dan tanggungjawab bersama (fardu kifāayah) untuk mengawasi, meluruskan penyelewengan, dan penghamburan terhadap sumber air yang dilakukan oleh negara, swasta, ataupun masyarakat umum.

\section{SIMPULAN DAN SARAN}

A. Simpulan

1. MK untuk mengakomodasi otoritas sumber tekstual hukum Islam di Indonesia, putusan MK berisi instrumen hukum Islam yang merefleksikan penghormatan para hakim terhadap norma hukum Islam dan transformasi prinsip-prinsip Syariah. Dalam pengujian undang-undang, MK menggunakan tolok ukur maqashid syariah dalam kerangka bernegara Pancasila menuju cita-cita nasional yang sejalan dengan idealisasi Baldatun Thayyibatun wa Rabbun Ghafur. Pada sisi yang lain, bahwa UUD 1945 yang kandungan setiap teks (pembukaan dan pasal-pasal) memiliki landasan nash dalam alQur'an dan sunnah.

2. Dalam Putusan MK No.2-3/PUU-V/2007 perihal Pengujian Undang-undang No.22 Tahun 1997 tentang Narkotika (Pidana Mati), Putusan MK No.12/PUU-V/2007 perihal Pengujian Undang-undang No.1 Tahun 1974 tentang Perkawinan (perihal Pembatasan Poligami), Putusan MK No.68/PUU-XII/2014 perihal Pengujian Undang-undang No.1 Tahun 1974 tentang Perkawinan (Perkawinan Beda Agama), dan Putusan MK perihal Pengujian UU Sumber Daya Air menunjukkan bahwa maqashid syariah merupakan tolok ukur, namun maqashid syariah tersebut diterapkan dalam kerangka negara hukum Pancasila.

\section{B. Saran}

1. Perlu adanya penegasan penggunaan tolok ukur maqashid syariah dalam putusan MK terhadap kasus pengujian undang-undang yang berdimensi kemaslahatan umat, mengingat Islam merupakan salah satu basis dasar Pancasila.

2. Penafsiran konstitusi tidak boleh bertentangan dengan Pancasila (termasuk Nilai-nilai Islam), namun dapat memberikan konstruksi kemaslahatan dalam perspektif Pancasila, misalnya pembatasan poligami dan perkawinan beda agama.

\section{DAFTAR PUSTAKA}

\section{Buku:}

Achmad, Yulianto dan Mukti Fajar, 2005, Dualisme Penelitian Hukum Normatif dan Empiris, Yogyakarta, Pustaka Pelajar.

Asshiddiqie, Jimly, 2006, Hukum Acara Pengujian Undang-undang, Jakarta, Yasrif Watampone. 
Imron, Ali, 2015, Legal Responsibility: Membumikan Asas Hukum Islam Indonesia, Yogyakarta, Pustaka Pelajar.

Mas'udi, Masdar Farid, 2013, Syarah UUD 1945 Perspektif Islam, Jakarta, Alvabet.

Palguna, I Dewa Gede, 2008, Mahkamah Konstitusi, Judicial Review dan Welfare State, Jakarta, Sekretariat Jendral dan Kepaniteraan MKRI.

Soekanto, Soerjono dan Sri Mamudji, 1985, Penelitian Hukum Normatif: Suatu Tinjauan Singkat, Jakarta, Rajawali Press.

Sumardjono, Maria S.W, 1997, Pedoman Pembuatan Usulan Penelitian, Jakarta, Gramedia Pustaka Utama.

\section{Jurnal:}

Alfitri, 2014, "Putusan Mahkamah Konstitusi sebagai Tafsiran Resmi Hukum Islam di Indonesia", Jurnal Konstitusi, Vol. 11, No. 2.

Sukarni, 2014, "Air dalam Perspektif Islam”, Jurnal Tarjih, Vol. 12 No. 1.

Yunus, Nur Rohim, 2015, "Penerapan Syariat Islam Terhadap Peraturan Daerah Dalam Sistem Hukum Nasional Indonesia”, Hunafa: Jurnal Studia Islamika, Vol. 12 No. 2.

\section{Makalah:}

Pimpinan Pusat Muhammadiyah, "Negara Pancasila sebagai Darul Ahdi Wa Syahadah", disampaikan pada Muktamar Muhammadiyah Ke-47 Makassar 16-22 Syawal 1436 H / 3-7 Agustus $2015 \mathrm{M}$

\section{Website:}

"Soal Hukuman Mati, Ini Pendapat Muhammadiyah", http://www.republika.co.id/beri-ta/duniaislam/islam-nusantara/15/01/19/nieysm-soalhukuman-mati-ini-pendapat-muhammadiyah, diunduh tanggal 1 Oktober 2017, pukul 21.00 